\title{
A Review of Krleža's Work in Light of Typology of the Characters and the Affinity for Addiction
}

\author{
Jasminka Matić ${ }^{1}$ \\ ${ }^{1}$ Neuropsychiatric Hospital "Dr.Ivan Barbot", Popovača, Croatia
}

\begin{abstract}
Krleža was blamed for misogyny [1] by some authors without any reason. The analysis of the subtle female psychology and sustained woman's power in relation with male's power, and ambivalence, is one of the biggest ode to female character recognized in his works. As an example for analysis and psychological review, an intimate tragedy, agony of Laura Lenbach and herrelation with two men lover as a hope, and husband, ex well-respected citizen, now just alcohol abuser and gambler without any character, supported by wife, is analyzed within the frame of tradition, gender-differentiated roles and responsibility in the sociosocietal context of the 1920s, contemporary moment, and eternal actuality of Krleža's work.
\end{abstract}

Key words: woman's nature, man's culture, alcohol and other addictions, responsibility, socio-societal context

Copyright $\odot 2019$ KBCSM, Zagreb

e-mail: alcoholism.kbcsm@gmail.com•www.http://apr.kbcsm.hr

\section{Introduction}

Writing about the demons and fairies of which Krleža's female characters are full, means writing about the subtlety and richness of their psychologies: passion, sensibility, sacrifice above all, and perseverance of a woman in an effort to make tomorrow a better day, the desire for love, humanity and the eternal search for the same. The drama "In Agony" is dominated by the power of a woman: in the character of Laura Lenbach she emanates through the longing for a man who, after many years of being with a "useless" husband, could make her love more meaningful

Correspondence to: Jasminka Matić,clinical psychologist, mr.spec.

Neuropsychiatric Hospital "Dr.Ivan Barbot", Popovača, Croatia

Daily Hospital for Alcoholism and Other Addiction

Unit of Psychodiagnostics and Psychological Treatments

Kopernikova 36,10 000 Zagreb, Croatia

Phone:+385 (44) 569341

E-mail: jasminka.matic@bolnicapopovaca.hr and make the desired love possible. The modernity of the drama, set in the early 1920 s, is reflected in its timelessness: similar intimate and social debacles continue today, a century after the agony whose characters are painfully and vividly portrayed by Krleža. As well as the environment of the recent 1920s, with an abundance of unhappy social circumstances yet again. In both, Croatia and Europe, the course of human destinies is crippled by a flurry of political change. So, where to look for hope when the concept of Europe is also called into question?

In Krleža's drama, the woman (Laura) gazes at a hopeful man (Križovec):

"I needed you that night, I so desperately needed you... I wanted a child from you that night..." [2] 
Laura's voice is the call of a tired woman who no longer wants to waste time with weak Lenbach who is an alcoholic husband and a failed nobleman. She wants to believe in the possibility of other and the better, which she deserves and can fight for. In the outcome of the first and the second acts she becomes aware that the next man she dreams of is not worthy of love and sacrifice. Unreliable, superficial, in the form of a chameleon, she instinctively adapts (to a new woman, to the authorities, to change), unaware of the depth and intensity of her experiences and the swirl of exaltation into which she falls because of her knowledge of betrayal. Krleža's drama contains a description of the psychological tension brought to perfections, as if it could be cut by a knife. Laura carries the plot of the drama in the manner of a man. Her thoughts strike sharp as the edges of a sword. Her powerful voice is the most dramatic link of Krleža's drama. Križovec and Lenbach are charaters that she leaves aside, walking by herself on a lonely path. In her mind, she places Lenbach in sheap taverns and money frauds, and Križovec in the semidarkness of a concert of his looks focused on the next lady. The woman (Laura) is left with submission, which she accepts strong, and painfully aware. Love enchantment is once again replaced by disappointment, emptiness and pain:
“..Please! Let me finish: please, forgive me! Everything was tasteless and shameless! I think I will be ashamed for the rest of my life! Yes, those were nerves, which can be under- stood! But what is under those nerves, under this outburst, what is under it, is all that is terrible: it is that which is not the nerves - it is guilt!.." [2].

Laura is traumatized for the second time by the importance of the weak, indecisive man. For the first time in an unhappy marriage with a failed Lenbach, a member of a noble reputation upon his return from his 3 -year sentence in Lepoglava. Bound by intoxication, lowness, gambling losses and fraud, she endures it for a long time: powerty and crisis make the worst of it. And she, once a baroness, is tired of day-to-day dewing for the newly rich, feels humiliated and exhausted. Repeated exposure to the weaknesses and insensitivity of the men in her vicinity reinforces her trauma and leads to resignation.

"Following the traditional patriarchal stereotyping of a female character, a woman is presented as a seamstress that has a lower position of power, social and intellectual infuence" [3].

Laura's position is that much harder because, after losing the benefits of a family background and a noble environment, she is still forced to endure a failed, alcohol-prone husband upon leaving prison, extorting herself to a tailoring shop. Despair is heightened by threats and insults from a drunken abuser, and in the traditional manner, Laura's tailored role radiates a feminine power stronger than a masculine one.

"In terms of traditional feminine and girlish culture and media, and well-known forms of the feminine genre from soap operas, melodramas, romance novels and women's magazines, women are also traditionally positioned far from sources of power and influence. The woman in the 1920s was far from "homo politicus". She is a dreamer, and the imagination excites the erotic but ignores her importance in the higher sphere" [3].

However, even when in lower position, the woman again rises above the mail characters with the strength of the character, significance and willingness for responsibility; 
Lenbach as a characteless character, drunkenly maddening from trying to appease to dangerious aggression; in finding money, he goest through all the stages of a characterless, hardened drunkard; hiding, lying, projecting, blaming others, figuring out how to make money and returning to the source of addiction. In doing so, he denies everything, responds by fleeing, with accusations, subjective interpretations, aggression and despair. He uses typical psychological defense patterns of addictive, passive-aggressive structure. It shows consistency only in its effort to snatch her hard-earned money and reject her divorce. In search of money as a way to attempt to settle the debt and spendings, he is ready and crawls in front of her.

Lenbach is a drunkard, and a failed gambler without dignity. Laura endures even the exposure and humiliation with style. As in the mirror, a reflection of contemporary society is painted today, with the defeat of the individual and the family in addiction same as it was 100 years ago as described in Krleža's drama. The couple's relationship in agony is riddled with hostility, his eagerness living in passion for a drink and gambling.

Even his suicide threates sound unconvincing. Her longing and hope end in hopelessness and the act of suicide represents the dramatic unravelling. His, and in the reworked outcome of the drama - hers, after being torn by the machinactions of her husband and her lover, this extraordinary woman of great sensitivity and dynamism (the only one) took responsibility for her own failure. Unhappy human destinies generate unhappy social circumstances, political change, dependency of a changed personality structure and intimate debacle. The individual agrees to shuttle in a bad relationship and environment, and in a weakness thends to withdraw, or step towards a change. Laura wanted to go with Križovec. She failed. Social circumstances, the collapse of the order, or a passive-aggressive husband and a weakling lover as a reason?

"Krleža's characters generally coincide with the usual conception of the modern individual as an "autonomous man" free from family and social ties that are made in the public sphere, while the woman is chained to the private sphere, and therefore invisible to the historians of modernity" [3].

Guided by fantasy,(after 3rd by the author amended part) [4] let us illustrate a possible outcome of Laura's confrontation with her husband in today's conditions: emancipated Laura closes the salon and sends Lenbach to be treated for his alcohol addictions. She gallantly leaves with style by leaving him some money, and deciding that she doesn't want to see him anymore as she wants to do something for herself. She says goodbye to her lover - weak Križovec, wishing him happiness with his seductress', wondering what she ever saw in him. She spends her savings that she has earned by her had work around the clock at the salon carefully and purposefully, perhaps for some new form of entrepreneurship. She leaves for Opatija, Venice or Vienna, far enough from parasites, weak and indecicive men.

Women have learned a great deal from the modern era when they were placed in the context of "nature", and men were placed in the context of a "society" [3].

Women take fate into their own hands. The context of social relations and perceptions of socially acceptable behavior is changing. But it is even easier for some men today to talk about a woman's way of dressing and being "for the mattress", than for the attitudes 
she represents in Parliament, or her immanent ability and role, and for the "wise man". It seems unjustified that Krleža, a connoisseur of the rich psychological dynamics within women's characters, a writer who, while writing about women, their strength and resistance to the challenges of life, was misogynistic. Is there a greater ode to the power of a woman than the role of Laura Lenbach who is alone in the solitude of the Zagreb's tailoring, as well as many other Lauras who are still working hard in order to maintain their families, and who fear what else might occur for her drunken husband from whom she has no use while his life is passing by, and whilehis responsibilities are being covered by her, or by their child, which in return generates a new kind of neurosis?

Reading Krleža today in order to see the round-about changes of life creates a feeling that everything comes back. Even when it seems that we as human kind and society have moved from a stagnating place and that individuals and society have matured, reality strikes in the middle of the face with power of misery and anguish. As well as war, poverty, hypocrisy and prejudice, lack of courage and character, dependence and weakness of the individual to resist all of that and remain a human being. By reading Krleža we are ensured of the eternal actuality of his works. The horror of recent war sufferings, aggression, repeated muddy roads filled with human and animal remains, family agonies, convince us of this, while seekingsolace and oblivion in intoxication, penetrating awareness of grave social crisis, enriching some and socially decaying the majority.

The foundation of the society, family and male-female relationships have been deeply destroyed after the last war, leaving deep furrows for the next generations! The last war has also interrupted family dynamics and created armies of additcs such as Lenbach. More and more people today are being referred to treatment with a pronounced safety and security measures of compulsory psychiatric or addiction treatment. The lines of disabled war veterans whose wives just like Laura, are sewing in silence, and are doing something to calm the children so they wouldn't be loud as the fathers are intensely nervous. The unrest of men are drowned in silence found in a glass while women, just as silent 100 years after the realistic intimate tragedies in lines of Krleža's work, are experiencing their own while literally and symbolically praying for the peace for their children.

"That wolf to a wolf, and not man to a man, this wild and untamed beast lives in a warm and painfully bloody network of irritated states, surviving and digesting in itself consciously with the unconscious, repressed and conquered with the overweight and vulnerable, bungry wit satiety, wild with the tamed and devouring self-destructive, stupid and shortsighted for centuries" [5].

Krleža's understanding of Freud's anthropology includes "the basic anthropological topics that $\check{Z}$ megač points out as a constant of Krleža's essayistic prose are man as ape, human aggressiveness, the idea of human volcanic nature in the wake of vitalist philosophy, in general, a metaphor that is always comparable to the animal, and human psychic features are compared as phenomena analogous to the elemental phenomena in nature. Conditionally, are these Krleža's Freudian generalizations?, asks $\check{Z}$ megač [6].

And it is as if we have never got away very far from the fake "hoch" Zagreb. The same, new-old Zagreb extends into the streets of the center. His stores are visited by a small group of citizens, others aware of a series 
of closed stores in Ilica, inexpensive secondhand shops and gold-buying shops that live during the day of crisis and the decline of the citizenry. Krleža briliantlly describes the decline of the old, great Austro-Hungarian Empire and the grotesque decay of economic and social relations today with a new form of crisis, decline of morality, hypocrisy and revisionism of history.

Who is better than Krleža when describing all the roles that women are willing to play in the effort to adapt, and dynamics of the strength and psychology of female characters, from Laura in Agony to female characters in "Wolf", daring Eve, used to life's challenges and out of nothing turning into a duper. Or Marijana Margetic who in the boondocks of Vučjak, despite the relentless hypocritical condemnation of the environment, takes care of children as best as she knows how, alone in a war-ravaged environment, aggression and self-destruction, distress and peril despite the last flashes of living desire for acceptanc, support and love.

Our demons are the product of our conscience. The demons we see in others, whether we are women or men, are the product of our projections and projections of the Society. Men's projections of women speak the most about them, their won fears and powerlessness, from life, political to erotic. A woman in Vučjak (as well as in the rest of the world) struggles daily with real life, while many men will wander long after the war, stunned by the whirlwind of dreaming about a woman or as substitute, not knowing which one to decide, feeling guilty, angry, or saturated with choices, floating between reality and dream, heaven and earth. In the meantime, they will seek comfort in a drink, mother, and another woman. Until he matures and/ or gathers some courage. Less mature, addic- tive-behavior prone personality leaves choices and leadership to another; mother, wife, authority. To a genetic or tribal father. Some have only partially complted the stage of rebellion against authority. Not everyone is ready for affiliation with a partner and family. They deny responsibility. Others find themselves selfish because they endanger the freedom to choose passivity.

Like Chagall's characters, a man (Krleža's Horvat, Lenbach, Križovec, Glembay father and son..) floats above the real life, wishing for a landing that he is not (as of yet) ready for, as he still needs maturity: to work, see the needs of others; both women and children. But the woman's struggle to abandon the patriarchal foundations of society is long. Conservative initiatives are vocal in calling for patriarchal family and views, questioning the woman's ability to make her own choices about herself, her future and her body. However, there are also progressive changes in strengthening the awareness of women and society towards "nonviolence", and legislation regarding the reporting and sanctioning of drunk husbands and abusers in general.

How strong must a woman be in a society built on unfortunate circumstances and war that left behind an endless sea of physically and mentally wounded, exhausted, weakened men and a fragile family? Is the fire in the fireplace still warm? Put on a fire, breathe in and sustain life: a woman is offered the opportunity to face the unacceptable patriarchal scenario and the (inevitably) epilogue of drama in the present day: abandon the role of the victim, move towards self-esteem, teach her daughter (and son), and influence their own destiny. The interpretation of the concept of "destiny" is replaced by an awareness of responsibility. Both female and male. A step towards a more humane society. 
Krleža's work and characters grew on the ashes of the World War I. From the first to the last, we are separated by a number of years, but it is as if we are not. We are reawaken from a difficult dream with vivid images of heartburn, the smell of smoke and tears exhausted from the sadness of loss, but also family dialogues with those executed in depression and alcohol, and the inability to assume a responsible role in the family.

Women carry the weight and mourn in silence. If they start drinking it will have more serious consequences for the family than when men are intoxicated. The reality is not black and white, nor is it a description of the timeless draggle of ego and super-ego, nor a metaphor in the charactes of the white, honorable, pristine and innocent femininity of Krleža's Angelika, who quietly circumnavigates Glembay's chambers, nor insanely passionate Castelli. Namely, Krleža's women are never pale in importance, the complement the dramas with dynamics imbued with male weakness and indecision, the urge to escape into weakness and addiction. In the "Glembay" cycle, Leon, the son of an aged and alcohol-depleted Glembay nobleman, indulges in the passion and embrace of stepmother Castelli, seemingly the victim of a demonic woman. To the man, to the victim, as if in the woman's embrace, he denies responsibility. It is easy to project contenct about a woman "demon" in the function of defense against her own inactivity, passivity, powerlessness, the need to escape from her. The story about the demon, or symbolic search for a mother, apostrophes the weakness. In the inability to assume his own responsible role, to realize himself as a strong male character in the drama, as well as in life, male-female relationship, family, society, man retreats: the weaker he is in the male role, the more he fears strong women.
Women never surrender. Neither working as hard as Canjegica, nor when choosing a "sponsored" role like Castelli: then, just like today, she is a woman who will begin an older, more prosperous and enjoyable life. Like the men looking for it. The more menacing emotion of male character in Krleža's dramas suggests that they tend to cope with life's adversities. It is as if I am sailing in a walnut shell, unsure of when to land on solid ground, and when it happens, they are afraid of some "demon" who will grab them, and for whom they (secretly) hope. The relationship with a demon is fraught with danger, but also with challenge. It is demonic in the realm of supernatural, the surreal. In the realm of the real it is harder to accept a woman and her power. Even today, sterotypes regarding the nature and value eof a woman are emerging in society, and part of society dobuts whether it can accept a woman in the integrity of all her roles. Krleža wondered about it in the modern times, and today the society wonders. Modern times record various forms of emancipation of women, the need for relaxation, comfort and imagination. Krleža's Melanija escapes addiction of reading novels that takes her to the most exciting places; by reading motivated by "feminine desire" emobdied in the main female character, the woman resisted daily life and patriarchal relationships built on strict family and church upbringing and ambiguities in which she recognized the tendency of men to mix the erotic and economic movement, leaving her, the woman, the only option to feel like a slave and easy". Krleža's defines Melanija's character "by her provincial origins and monastic upbringing that she failed to liberate, which is further manifested by drinking large quantities of wine, card reading and superstition. She fully justifies the label of "impossible life 
phenomena" by combining a series of contradictions, a dark Croatian province and the modern European life, peasant superstition and modern science and philosophy" [3].

Unfortunately, intoxication is more common in women today, and it talks about the negative aspects of emancipation. The sources of comparisons for the male and female, for the nuances of the spiritual, for the search for strengths and weaknesses of the characters, especially the female ones, are unimaginable in Krleža. Along with a man, perceived as weak, who needs help, one usually finds a woman in the role of savior. She works hard to help a man who remains so weak and immature, without responsibility. She provides support in changing the role of a daughter, wife, and mother. Transgenerationally, women is used to it, just as she gets him used to that as well. Krleža, who "dealt with them" as well as with himself, he knew how to expose his soft side (gentle, or thus "female"?) by being apologetic for reconciliation, tolerance and common sense in thinking about war, to the left, changes related to the Croatian language, and calling for maturity with changes in the society. Krleža, whose strength of eruptive words and excallation of the characters we witness today, wrote the gentlest letters to his wife [7].

The role of personal autonomy, maturity and responsibility can be considered in the context of a successfully separated separation from the Mother, Father, State, Nation, relationship to religion. Separation is a job for life. "National culture is in principle as valuable as culture really is", said Matvejević [8], together with Čengić and Lasić, one of the most frequent intercutors and better acquaintances of Krleža. In society, the pendulum swung in the direction of patriarchal values; both women and men, are responsible for their choices. Just like Krleža's characters, both women and men, and us in our reality - we are mature in the moment when we are able to accept the mistakes of our parents as well as our own, and move on. Regressively attached to the mother, in the struggle wit hthe authority of the father, uncertain of the identity of the homeland, it is easier for the immature structure to glorify the imaginary Nationan and find a place under the auspices of the Church (without true faith and spirituality). And this loses the meaning of the real connection between the individual, family and society. By ceasing escape from responsibility by both the individuals and the society, and closing our eyes to problems (and in the form of addiction), it is possible to realize male-female relationships with equal and responsible actors and to heal relationships, familiees and society. In a similar message, Krleža is justifiably considered to be the universal classic in his works.

\section{Acknowledgements}

None.

\section{Conflicts of interest}

None to declare. 


\section{References}

1. Stančić M. Krležina navodna mizoginija, 2013; Available from http://www.zarez.hr/clanci/ krlezina-navodna-mizoginija

2. Krleža M. Glembajevi, Drame: U agoniji, Zagreb, Sabrana djela, sv. 4, Zora, Zagreb. 1962;501-505.

3. Grdešić M. Popularna književnost i shopping; Predodžbe ženskih žanrova u gospođi Bovary i tri kavaljera frajle melanije U Komparativna povijest hrvatske književnosti, Zbornik radova IX Hrvatske književnosti XX stoljeća u prijevodima;emisija i recepcija, Književni krug Split. 2008;247-279.

4. Krleža M. Sabrana djela Miroslava Krleže, Zora, Zagreb;1956.

5. Matijašević Ž. Krležino viđenje Freuda u Komparativna povijest hrvatske književnosti, Zbornik radova IX (Hrvatska književnost XX stoljeća u prijevodima;Emisija i recepcija, Uredile Cvijeta Pavlović i Vinka Glunčić-Bužančić, Biblioteka Knjiga Mediterana 48, Split: Književni krug Split. 2008;237-246.

6. Žmegač V. Krležini europski obzori, Znanje, Zagreb;1976.

7. Krleža M. Bela dijete drago: Pisma, Naklada Ljevak, Zagreb;2015.

8. Matvejević P. Nacionalnost postaje važnijom od humanosti [Internet]. 2019 [cited 10.09.2019.] Available from https://www.autograf.hr/predragmatvejevic-nacionalnost-postaje-vaznijom-od-humanosti/

\section{Osvrt na djelo Krleže u svjetlu tipologije likova i sklonosti ovisnosti}

Sažetak:- U svjetlu pojačanog gubitka sigurnosti, stabilnosti, smisla i motivacije, čovjek je danas u očajničkoj potrazi za podrškom i humanijim okruženjem. Slično problemima koje je opisivao Krleža i psihologijom definiranom njegovim karakterima gdje je uspio izložiti galeriju izgubljenih likova počevši od starog Glembaya u drami "U agoniji" (sklonog ovisnostima, ambivalenciji, gubitku snage, agresivnosti i slabosti,koristeći druge u svrhu osiguranja podrške, i snažne, ali iscrpljene supruge Laure motivirane da ga ostavi tražeći drugi život), današnji je čovjek razapet između shizofrenih poruka, suočen s gubitkom vrijednosti i hijerarhije potreba:Važnost stabilne strukture i značenja generalno nedostaje u sklopu obitelji, radne okoline, društva, nacije i svijeta. Krik za podrškom i ljudskim pristupom ponovno se čuje,ne samo iz Krležine drame“ $U$ agoniji“,već i nakon posljednjeg rata u Hrvatskoj, svih suvremenih ratova u drugim zemljama, od ljudi koji pate, ljubavnika, vojnika, izbjeglica,bez obzira gdje, i kada, nakon što se osjete jadnima, i ispaćenima, ljudi nastoje pronaći rješenje u alkoholu, kartanju, kocki, drogi, internetu i drugim ovisnostima. Ponovno mnogo posla za psihijatre, psihologe i umjetnike: $U$ svjetlu univerzalnih humanih tema i ljudskih reakcija, literatura koju je za sobom ostavio Krleža je nepresušna inspiracija za sve, i one koji pate, i profesionalce.

Ključne riječi: ženska priroda, muška kultura, alkoholizam i druge ovisnosti, odgovornost, društveni kontekst 